\title{
Positioning of the Republic of Tatarstan in the Volga Federal District
}

\author{
Rozhko M.V.
}

Kazan Federal University, Institute of Management, Economics and Finance, Kazan, 420008, Russia

Maklakova N.V.

Kazan Federal University, Institute of Language, 420008, Kazan, Russia

\section{Doi:10.5901/mjss.2014.v5n24p263}

\begin{abstract}
At the moment the struggle of the regions for investment and innovations has increased. In this struggle the regions that try to increase their competitiveness in the frames of various territorial associations, get the advantage. In connection with this the question of evaluation of competitiveness and positioning of the regions is becoming rather urgent. At that both the purely economic, as well as the complex approaches to the assessment of competitiveness of regions are possible. But taking into account that the increase of competitiveness of the region must be accompanied by the improvement of the quality of life which is impossible without improving social and environmental conditions, the assessment of competitiveness should be carried out taking into account both economic and non-economic indicators. The concept of competitiveness should be built up with interbalance of all principles of social-economic development. Competitiveness of the region should be considered by the whole complex of indicators that are components of the subsystems: population, economy, infrastructure and ecology. The aim of this work is to review the positioning of the Republic of Tatarstan in the framework of the Volga Federal District, as well as the analysis of changes of the position of the Republic for the period from 2007 to 2011. The Republic of Tatarstan is one of the most developed regions of the Volga Federal District which unites fourteen regions of Russia. The method based on a diagnostic set of indicators, including twelve indicators, is used for assessment. These indicators characterize the gross regional product, the turnover of companies, innovative activities of companies, density of the transport network, emission of pollutants into the atmosphere, the capital assets of companies, life expectancy, population morbidity, the level of education of population, household income, coverage of television broadcasting, fixed capital investment.
\end{abstract}

Keywords: region, competitiveness, positioning, assessment (evaluation), Tatarstan.

\section{Introduction}

Nowadays evaluation of the competitiveness of territorial entities has become one of the most urgent problems of economic life. It is particularly important in connection with the deepening of the globalization process and the start of the transition of society to the post-industrial stage of development. In conditions of the post-industrial development of the regions the role of their positioning and competitiveness in the struggle for investment, innovation, high technologies has significantly increased (Porter, 1990; Enright, 1993).

Recently years, a lot of works devoted to the study of the concept of competitiveness have appeared (Конкурентоспособность России..., 2003; Пилипенко, 2006; Kaliuzhnova, 2011; Bagautdinova et al., 2012). In some of these works there are attempts to develop the methodology for assessment of competitiveness. But in the majority of cases, the assessment of competitiveness either includes only the economic indicators, or is directed towards the economic perspective.

The study of competitiveness of the region only from the economic perspective cannot be completely objective. The concept of competitiveness should be built up with inter-balance of all principles of social-economic development. It is important to assess not only the condition of the economy of the region, but the influence of the economic activity on the environment of the region as well, i.e. it is necessary to assess the condition of ecological and economic systems of the region (Trofimov et al., 2010). It is also important to take into account the demographic potential of the territory (Gabdrakhmanov and Rozhko, 2014; Gabdrakhmanov and Egorov, 2013; Denmukhametov and Zjablova, 2014). Assessment of the region should be made with the account of the study of quality of life of the population (Фахрутдинова, 2011).

Competitiveness of the regional economic system should be viewed by such essential parameters as population, economy, infrastructure and ecology. There is no doubt that the main aim of any concept connected with the 
development of territorial entity, its positioning and assessment of the degree of competitiveness should be attended with improvement of the quality of life which is provided by the stable economic growth, increase of income of population, increase of investment in the economy, improvement of quality of social services.

Assessment of competitiveness and positioning can be made from the position of economic-geographical zoning, and at different levels - of the countries, regions, and other smaller regional systems (Трофимов, etc. 2011).

\section{Methodology}

Competitiveness of the region should be considered by the whole complex of indicators that are components of the subsystems: population, economy, infrastructure and ecology.

In the work devoted to the competitiveness and positioning of regions (Трофимов \& other authors, 2008), the structured system of blocks - components of competitiveness was developed. On the basis of this system a set of diagnostic parameters was formed.

Assessment of competitiveness and positioning can be made from the position of economic-geographical zoning, and at different levels - of the countries, regions, and other smaller regional systems.

The aim of the work is to review the positioning of the Republic of Tatarstan in the framework of the Volga Federal District.

Calculation is made on the basis of the diagnostic set of indicators (it was formed in the previous works) (Тросримов and others, 2009) It includes twelve indicators:

1. Gross regional product per capita (roubles);

2. Indicator of the turnover of companies unrelated to exploitation of natural resources (bln. rubles) (POONPR);

3. Degree of innovative activities of companies (\%);

4. Density of the transport network ( $\mathrm{km}$ for $1000 \mathrm{~m} 2$ of the territory);

5. Emission of pollutants into the atmosphere per capita (tons);

6. Indicator of the capital assets of companies;

7. Expected life expectancy at birth (years);

8. Morbidity for 1000 people;

9. Indicator of the level of education of working population (ILEWP);

10. Share of population with income below poverty line (\%);

11. Share of population who have coverage of television broadcasting (\%);

12. Fixed capital investment per capita (rubles).

The score rating method at which the total score was obtained by summing of the weighted scores of all indicators, was used for the assessment and rate setting of indicators.

The indicator of GDP per capita as the roundup indicator characterizing the economic activity of the region, was chosen as a roundup indicator.

The five-point scale was used for assessment. For each indicator, the reference points, the distance between which was divided into five parts, were determined. Depending on the segment the value of the indicator was in, the value from one to five was assigned to it. The inverse scale was used for negative exponents.

As a result, the total sum of scores was found for each region. Based on this sum of scores, the regions were ranked from 1 to 14.

For the calculation we used the data of State Statistics (Regions of Russia, 2012).

\section{Results}

On the basis of the data of 2011, in terms of scores the Republic of Tatarstan was first among the regions of the Volga Federal District. The Republic received a total score 32.26.

Nizhny Novgorod region with a total score 26.82 is closest pursuer of Tatarstan. Permsky region $(23,86)$, Samara region $(23,13)$ and the Republic of Bashkortostan $(22,79)$ Coming up with a slight delay follow it.

The Republic of Tatarstan managed to take the first place in the Federal District due to the fact that by 9 of 11 analyzed parameters the Republic gained the maximum score. In this case, the Republic of Tatarstan is a leader in the Federal District by six parameters: the republic has the highest values of POONPR, of the level of innovation activity of companies, of the indicator of the capital assets, of life expectancy at birth, and investment in fixed capital per capita, as well as the lowest -among the subjects of the district - share of population with income below poverty line.

Such high figures show the high levels of socio-economic development and competitiveness of the Republic of 
Tatarstan.

However, such high results by 9 indicators do not mean that the republic has no problems. From the remaining two indicators Tatarstan got just 1 point in terms of the level of education of the working population. By this indicator, the republic takes the $10^{\text {th }}$ place in the district, it is ahead only of the Chuvash Republic, the Republic of Bashkortostan, the Kirov Region and the Udmurt Republic.

Low value of PUORN is explained by the fact that despite the relatively high percentage of workers with higher education (29.7\%), the percentage of workers with secondary vocational education is very low in the republic (19.2\%, which is the worst figure in the Volga Federal District ). As a result, the lag of the Republic of Tatarstan from the leading by this indicator - Samara region is very significant (in Tatarstan, the total share of the working population with higher and secondary vocational education is $50 \%$, in the Samara region it is $67.3 \%$ ).

It is also interesting to compare the calculations made on the basis of the data for 2011 with the earlier studies using the statistical data for 2007 and 2010.

In 2007, the Republic of Tatarstan was a part of the group of leaders, taking the $2^{\text {nd }}$ place in the Volga Federal District by the total score and lagging only from the Samara region. Then the Republic of Tatarstan received the highest score in 5 indicators, and by all indicators received at least 2 points.

In 2010, the Republic of Tatarstan took the $1^{\text {st }}$ place in the Federal District by the total score, with the highest score by 8 indicators and the lowest score by one indicator.

Let's consider the rating change of the Republic of Tatarstan by some indicators.

In all three studies the Republic of Tatarstan received the maximum score by five indicators: emissions of pollutants into the air, per inhabitant; life expectancy at birth; share of population with income below poverty line; share of population who have coverage of television broadcasting; capital investments per capita.

By 2010, the Republic had increased its rating by such indicators as POONPR, density of transport routes, the indicator of capital assets. In this case, the republic has lost 1 point by the indicators of PUORN and morbidity for 1000 people. The latter circumstance can cause some concerns about the quality of human resources available in the Republic.

Comparing the results of the Republic of Tatarstan for 2010 and 2011, it is possible to say about an increase of the number of scores by the level of innovation activity. For example, in 2007 and 2010 the Republic had only 3 points by this indicator, and in 2011 it became a leader with 5 points. This is a very positive development, as far as in the previous studies the level of innovative activity was one of the weak points in the positioning of the Republic of Tatarstan.

\section{Discussion}

Today the study of competitiveness of the regions, their positioning is very relevant. The regular reports on this topic at various conferences of different levels are the evidence of it. In particular, a lot of provisions of this article were discussed at several conferences on various aspects of development of the regions.

At that the evaluation method of ranking of the regions with relation to their competitiveness is the main discussion point in most cases. As a rule, there are different points of view on this issue in the framework of the discussion. But in our opinion, only an integrated approach can provide an objective assessment of the competitiveness of the region.

\section{Conclusion}

In the frames of the work the assessment of the positioning of the Republic of Tatarstan in the framework of the Volga Federal District was made, the changes of positions held by Tatarstan in the District from 2007 to 2011 were analyzed. In the future, it is necessary to examine the results obtained with the account of positioning of the Republic of Tatarstan in the framework of the territorial associations of a higher - in comparison with the Federal District - rank, as well as to study the differences within the region.

\section{Statements}

In 2011 the Republic of Tatarstan took the first place in the Volga Federal District. Tatarstan is the leader in the Federal District by six from eleven analyzed indicators, but it has a problem with one of the analyzed indicators.

In 2007 Tatarstan took the second place in the District, but by 2010 was able to climb to the top and again took the $1^{\text {st }}$ place.

In general, we can come to conclusion that today the Republic of Tatarstan is the most developed region of the 
Volga Federal District from the point of view of the level of socio-economic development and competitiveness, and it also tends to develop their leadership.

\section{References}

Bagautdinova, N., I. Gafurov, N., Kalenskaya and A. Novenkova, 2012. The regional development strategy based on territorial marketing (the case of Russia) World Applied Sciences Journal, 18. ${ }^{1}$ SPL.ISSUE., 18: 179-184.

Denmukhametov, R.R. and O.V. Zjablova, 2014. Geodemographic situation in the Republic of Tatarstan. World Applied Sciences Journal. Volume 30, Issue 11, Pages 1684-1688.

Enright, M.I., 1993. The Geographical Scope of Competitive Advantage. Stuck in the Region? Changing scales for regional identity. Utrecht, Sciences about Earth, 1: 145-155.

Gabdrahmanov N. and D- Egorov, 2013. Report "The role of geo-demographic infrastructure facilities in the regional development of human capital" // WARSAW REGIONAL FORUM 2013 Territorial capital - concepts, indicators and policy by the Institute of Geography and Spatial Organization Polish Academy of Sciences, together with the Ministry of Regional Development of the Republic of Poland and Polish Geographical Society, Warsaw, p. 57

Gabdrakhmanov N.K. and M.V. Rozhko Positioning of Volga Federal District Regions by Demographic Situation Index // World Applied Sciences Journal, Volume 30 Number 6, 2014. - pp.792-795.

Kaliuzhnova, N.Y., 2011. Institutes of regional development and competitiveness in the conditions of modernization. The region's economy, 2: 65-72.

Porter, M.E., 1990. The Competitive Advantage of 2012. Nations. Harvard Buisness Review. March-April, pp: 73-93.

Trofimov A.M., M.V. Rozhko and D.Z. Kucheryavenko, 2010. Critical and uncritical regions. Environmental Radioecology and applied ecology, Vol. 16, No. 3-4, pp. 3-5

Konkurentosposobnost Rossii v globalnoy ekonomike /Pod nauch.rukov. Dyinkina A.A., Kurenkova Yu.V. RAN, IMEMO - M., Mezhdunarodnyie otnosheniya, 2003. - 376 s.

Pilipenko I.V. Konkurentosposobnost i forma organizatsii proizvodstva v postindustrialnyih usloviyah //Postindustrialnaya transformatsiya sotsialnogo prostranstva Rossii. Shestyie sokraticheskie chteniya. - M.: IG RAN, 2006. - S.124-142.

Regionyi Rossii. Sotsialno-ekonomicheskie pokazateli. 2012: R32 Stat. sb. / Rosstat.

Trofimov A.M., Rubtsov V.A., Komarova V.N., Rozhko M.V. Sotsialno-ekonomicheskoe razvitie i konkurentosposobnost regiona /I Ekonomiko-geograficheskiy vestnik Yuzhnogo federalnogo universiteta. - 2008. - \#5. - S. 28-34.

Trofimov A.M., Rubtsov V.A., Sharyigin M.D., Komarova V.N., Rozhko M.V. Pozitsionirovanie i konkurentosposobnost regionov v protsesse sotsialno-ekonomicheskogo razvitiya // Geograficheskiy vestnik. - 2009. - \#2 (10). - S. 68-77.

Trofimov A.M., Rubtsov V.A., Tumashev A.R., Rozhko M.V. Konkurentosposobnost i pozitsionirovanie munitsipalnyih obrazovaniy Respubliki Tatarstan // Vestnik Udmurtskogo universiteta, 2011 \#4. - S.145 - 148.

Fahrutdinova L.R. Institutsionalnoe proektirovanie kachestva zhizni v rossiyskoy ekonomike // Segodnya i zavtra Rossiyskoy ekonomiki. 2011. \# 43. S. 37-42. 